\title{
PLUMAGE VARIATION IN BERING SEA PLECTROPHENAX BUNTINGS AND THE SPECIFIC STATUS OF MCKAY'S BUNTING
}

JACK J. WITHROW, University of Alaska Museum, Fairbanks, Alaska 99775; jjwithrow@alaska.edu

ABSTRACT: McKay's Bunting (Plectrophenax hyperboreus) is an enigmatic and little studied passerine that breeds only on one of the most isolated groups of islands in North America. Recent field work on those islands, St. Matthew and Hall, and the nearby Pribilof Islands produced specimens of breeding McKay's and Snow Buntings ( $P$. nivalis) demonstrating that plumage variation in both taxa is significant, probably not related to age after the first year, and varies continuously between the extremes within a taxon. The extreme of one closely approaches that of the other. McKay's Buntings are paler overall and levels of black pigmentation of the wings, back, and tail, in conjunction with sex, allow qualitative diagnosability of these taxa by plumage in nearly $100 \%$ of individuals if enough of the bird can be seen. Levels of plumage variation are congruent with recent genomic work suggesting their relationship is extremely close. Current information suggests that McKay's Bunting is not a biological species and should be considered a subspecies of the Snow Bunting.

McKay's Bunting (Plectrophenax hyperboreus) is one of the least studied passerines in North America. It is endemic to the Bering Sea, breeding only on St. Matthew and Hall islands and wintering along the eastern coast of the Bering Sea (see Lyon and Montgomerie 1995). Extralimitally, it has been reported from the Chukchi and Kamchatka peninsulas (summarized by Arkhipov and Lawicki 2016) and coastal British Columbia, Washington, and Oregon (e.g., Campbell et al. 2001, Marshall et al. 2003, Wahl et al. 2005, Nehls 2014, Mlodinow and Bartels 2016). Probably fewer than 250 specimens of McKay's Bunting exist in the world's collections, and rarely has any one ornithologist been able to view more than a handful of specimens together. Consequently, the level of variation within this taxon and nearby populations of the Snow Bunting (P. nivalis) has been underappreciated.

Field work on St. Matthew and Hall islands in early June of 2018 and St. Paul Island in the Pribilof Islands in late May 2018 resulted in the collection of 20 male and 20 female McKay's from St. Matthew and 17 male and 13 female Snow Buntings from St. Paul Island. The surveys were part of the University of Alaska Museum's (UAM) continuing efforts to archive, through specimens and their associated parts, a record of the avifauna of Alaska (see Winker and Withrow 2013, 2017). The most recent estimate of the population of McKay's Bunting is 30,000 individuals (Matsuoka and Johnson 2008), with an annual mortality in the range of $\sim 30-40 \%$ (Lyon and Montgomerie 1995). Before 


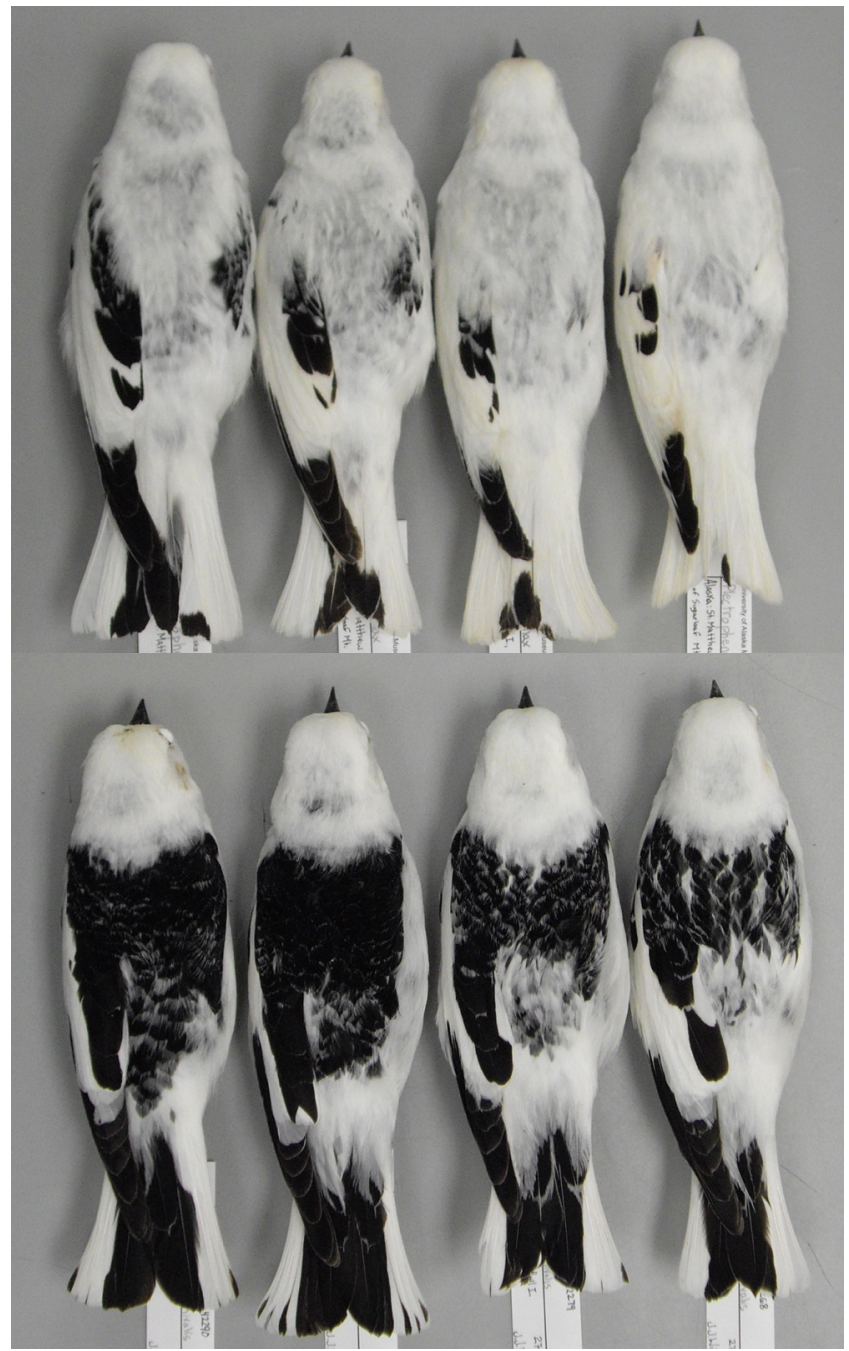

FIgure 1. Examples of male McKay's Buntings from St. Matthew Island (top; left to right, UAM 42263, 42237, 42246, and 42232) and male Snow Buntings from St. Paul Island (bottom; UAM 42290, 42289, 42279, and 42268), collected in early June and late May respectively. The rightmost McKay's (UAM 42232) is at the pale end of the spectrum. The middle two birds are fairly typical, while the leftmost bird shows more black in the scapulars than do most McKay's Buntings on St. Matthew Island. Male Snow Buntings on St. Paul I. vary considerably in darkness, and some could be mistaken for female McKay's without careful examination of the wing (see Figure 4). Very fine black streaks in the mantle of McKay's seem to be more common in fall/ winter (i.e., fresh plumage) and/or first-year birds (see Figure 5 for the extremes), but most of these streaks, if they are present at all, have worn off by summer. 


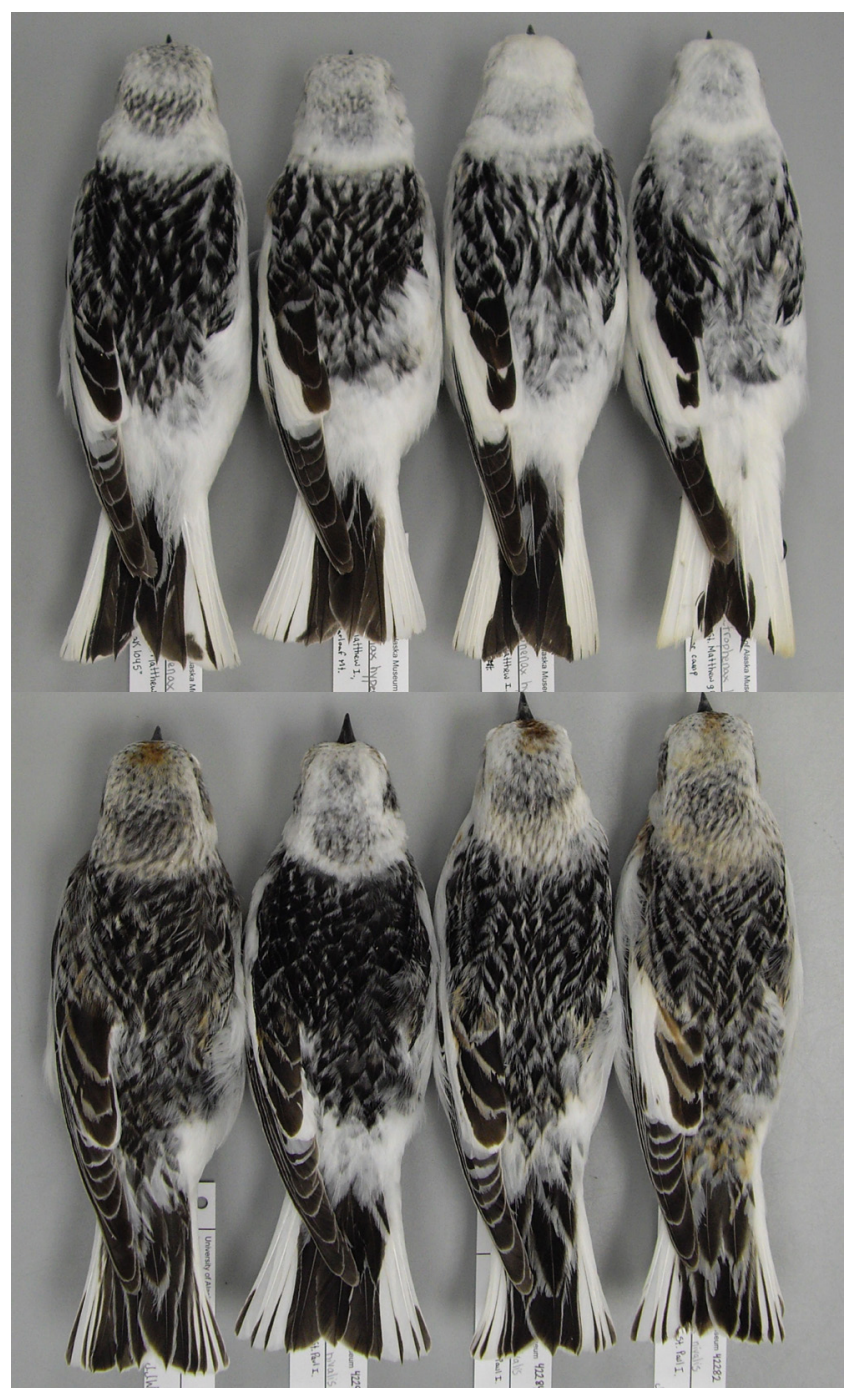

FIgURE 2. Examples of female McKay's Buntings from St. Matthew Island (top; left to right, UAM 42250, 42238, 42234, and 42264) and female Snow Buntings from St. Paul Island (bottom; UAM 42278, 42294, 42284, and 42282) collected in early June and late May, respectively. The middle two McKay's are typical; the rightmost and leftmost birds represent the pale and dark extremes. Note that the palest example of McKay's is one year old, suggesting that individual variation is at least as great as any variation due to age. The darkest summer-plumaged McKay's can be impossible to distinguish from a female Snow Bunting when details of the wing and tail coloration are obscured. Even then, with samples sizes high enough, some examples will likely defy categorization (see text). 


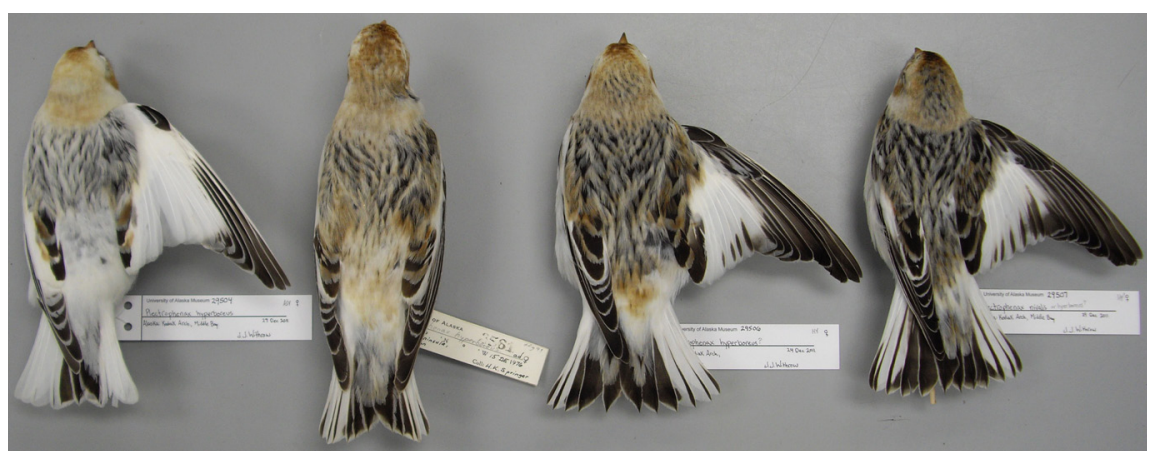

Figure 3. Four female Plectrophenax buntings collected in December; left to right, UAM 29504, 3561, 29506, and 29507. The leftmost bird, over one year old, is a typical pale female McKay's. The bird second from left is a first-year bird collected on the Seward Peninsula on the same date as other McKay's Buntings and is tentatively identified as that species from the pale rump, narrow black markings on the mantle feathers (hard to see in this photo), and a third rectrix that is about $1 / 3$ dark (not visible in photo). This bird has dark markings (again not visible here) on the outer vane of the five outermost secondaries, as does the bird second from right. This specimen, UAM 29506, despite being a first-year bird, is quite similar to UAM 3561 but is probably a Snow Bunting on the basis of its darker rump, third rectrix being mostly dark, and mantle feathers with broader black "V"s (easier to see in hand when feathers can be examined individually). The bird at the far right (first year) is still on the pale end of the Snow Bunting spectrum, mostly through a reduction in the extent of rusty fringing. The palest winter-plumaged female Snow Buntings can look nearly identical to the darkest winter McKay's, and it is likely that not all birds can be safely identified in the field without exceptional views. In a large sample some would likely be perfectly intermediate. Note the provisional identifications on the Snow Bunting labels from when they were prepared that are at odds with concepts I advance here.

2018, no specimens of McKay's Bunting had been collected from St. Matthew Island in early June, let alone a series from which the bounds of "normal" breeding plumage could be easily inferred. The majority of McKay's Bunting specimens from St. Matthew Island have been collected in late summer (July, August) when the plumage of adults is extremely worn, making detailed plumage comparisons difficult. In comparisons of Plectrophenax buntings, it is important that specimens be in similar states of plumage wear because the birds' appearance changes markedly through the year and wear accelerates during the breeding season. Plectrophenax buntings follow a complex basic molt strategy (as defined by Howell et al. 2003), with juveniles undergoing a partial preformative molt in which they replace body feathers and a few wing coverts only (Lyon and Montgomerie 1995). Both the preformative and prebasic molts take place from late July to September, and the breeding plumage is acquired through subsequent wear (Lyon and Montgomerie 1995). The pattern of white and black pigments within a feather that manifests as the breeding plumage of these buntings is much harder to discern in fresh winter-plumaged birds, when the rusty fringes of many feathers obscure underlying patterns.

Specimens collected in 2018 were prepared as round skins with a separate 


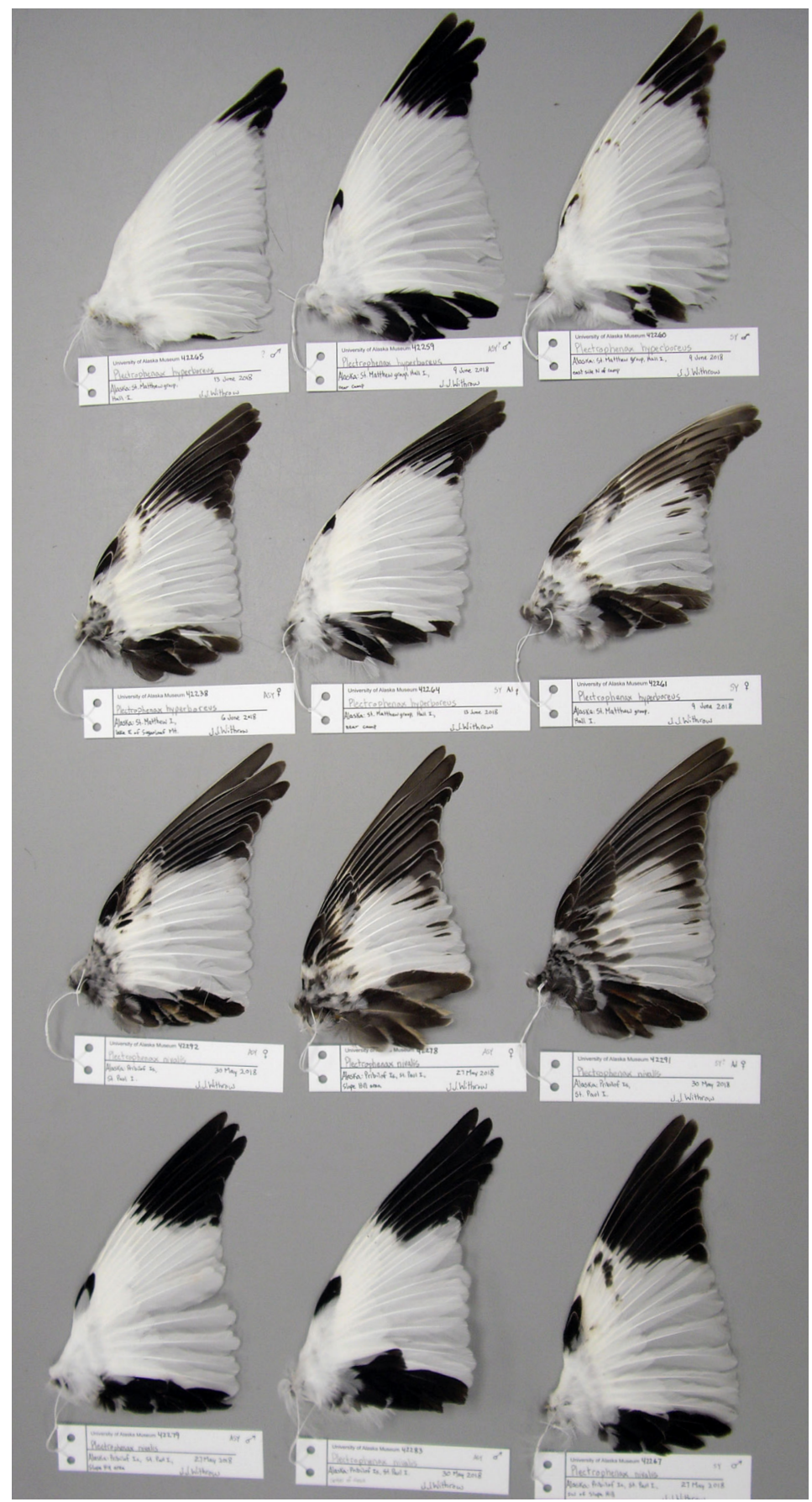


spread wing and associated tissue, stomach, and gut samples. They were sexed by examination of the gonads. All but one of these birds were collected at random, without regard to coloration, the sole exception being a male McKay's Bunting with darker scapulars on Hall Island (Figure 1). This series, part of the largest single museum holding of McKay's Bunting (140+), plus a large series of breeding Snow Buntings from Alaska, provided a solid foundation from which detailed plumage comparisons can be made. In UAM's specimens, the 2018 series in particular, it is obvious that there is significant variation in the extent of black pigmentation in both taxa. Here I provide photographs of what can be subtle identification criteria and provide examples of instances where criteria have broken down or where previous authors have overgeneralized, thus outlining previously underappreciated levels of variation in these birds. I conclude by summarizing what this expanded understanding of the phenotype, along with new genomic data, suggests taxonomically for the genus Plectrophenax.

My comparisons are largely between the series of $P$. hyperboreus and $P$. nivalis townsendi from 2018 (see above). Assessment of other Beringian subspecies of the Snow Bunting is beyond the scope of this paper, although the conclusions about separation of hyperboreus from the rest of nivalis are no doubt transferrable. All specimens from Beringia, if not the Holarctic, need to be reexamined to assess the validity (diagnosability, sensu Patten and Unitt 2002), in relation to nominate nivalis \{type locality Lapland\}, of vlasowae (Portenko, 1937)\{Wrangel Island\}, pallidior (Salomonsen, 1947)\{Amurland\}, and townsendi (Ridgway, 1887) \{Otter Island, Pribilof Islands\}. For example, the distinction between townsendi and nivalis "should be understood ... [as] a conventional arrangement due to the need of drawing a dividing line where there is none in nature" (Swarth 1934:55). Dementev and Gladkov (1970) synonymized vlasowae with townsendi. I am skeptical that the Bering Strait represents a meaningful taxonomic line in the Snow Bunting, e.g., three June skins of nivalis from near Anadyr, Russia, do not appear different from Alaska birds in plumage (University of Washington Burke Museum 82265, 82266, and 82268). See Lehman (2019) for observations of probable continental interchange. It is interesting to note that both vlasowae and townsendi were described as larger island forms. Portenko (1989) clearly restricted vlasowae to Wrangel Island (cf. Dickinson and Christidis 2014), and only after the original description was the name broadened through the principle of priority to represent birds apparently paler than the nominate subspecies occurring in most of Russia (i.e., Salomonsen's pallidior; see Vaurie 1956, Lyon and Montgomerie 1995, cf. Portenko 1989).

FIgURE 4. Spread wings of late May-early June buntings, from top to bottom, three male McKay's Buntings from St. Matthew Island (left to right, UAM 42265, 42259, 42260), three female McKay's Buntings from St. Matthew Island (UAM 42238, 42264, and 42261), three female Snow Buntings from St. Paul Island (UAM 42292, 42278, and 42291), and three male Snow Buntings from St. Paul Island (UAM 42279, 42283, and 42267). The rightmost wings are all from one-year-old birds, the rest are from birds at least two years old, except for the middle female McKay's (UAM 42264), which is a from a very pale one-year-old (see Figure 2 ). In the primary coverts of first-year male Snow Buntings, the dark is restricted to the tips of the coverts, unlike in female McKay's, where the dark (when present) is more uniformly distributed and often extends to the base of the feathers as well (see text). Note also that some male McKay's Buntings in their second cycle have the alula partially dark (see text). 


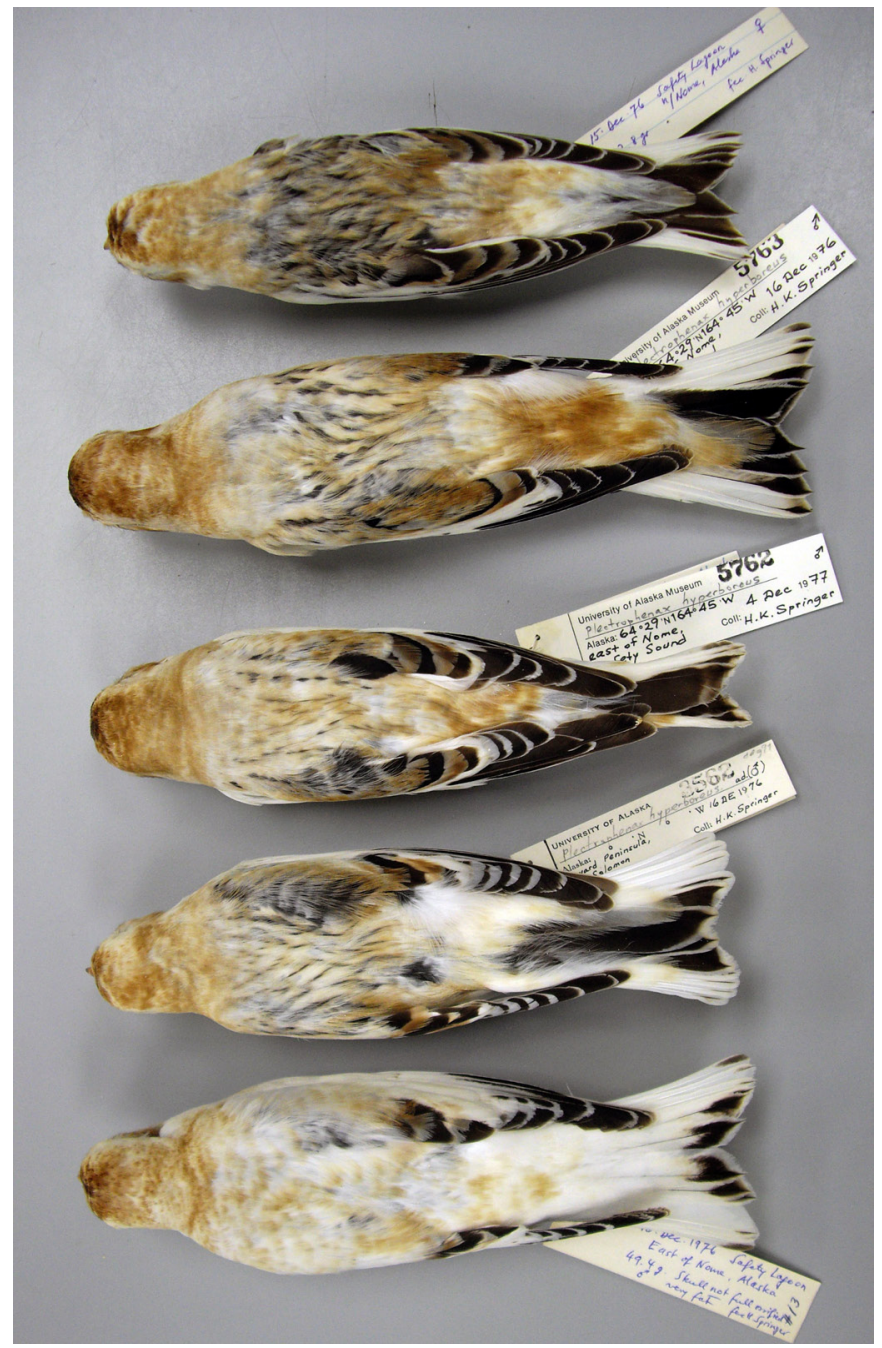

Figure 5. Five McKay's Buntings collected in December from the Seward Peninsula, from top to bottom, UAM 8534, 5763, 5762, 3562, and 8533. The bottom bird is a typical male over one year old without any black in the mantle area. The birds second, third, and fourth from bottom, all males (age greater, less, and less than one year, respectively), show progressively more black in the mantle. The top bird is a first-year female for comparison. Note that the shape of the black markings in the mantle of UAM 5763 differs from their shape in the female, but in this fresh plumage, without close scrutiny, this bird could be mistaken for a female if the paler wing was not discernable. In summer, after the rusty fringing has worn away, UAM 5763 would probably look quite similar to a putative hybrid photographed on St. Matthew by Peter LaTourrette (see figure 10 in Rogers 2005). A minority of male McKay's Buntings show some very fine black streaking in the mantle (usually less even than in these three examples, see text), but the extent to which those with significant streaking may represent intergrades or the extremes of standing variation within McKay's is not known. 


\section{IDENTIFICATION OF McKAY'S BUNTING}

Male McKay's Buntings differ dramatically from male Snow Buntings by having a white as opposed to black mantle and back. The black areas of the wings and tail are also reduced in male McKay's. Females differ less dramatically, but again McKay's shows a general reduction in the level of black pigmentation in the mantle, back, head, wings, and tail. Several detailed descriptions of McKay's Bunting that reference its distinction from the Snow Bunting have been published (e.g., Byers et al. 1995, Pyle 1997, Rogers 2005). The reader is referred to those works for feather-tract-by-feather-tract descriptions and an overview of identification criteria. Here I extend that foundation by focusing on the frequent and significant variation present in individuals and populations. By showcasing exceptions to some generalizations and focusing on cases and aspects that are likely to cause identification confusion, I hope that the reader will be better able to assess confusing or intermediate birds. The few places where my findings diverge from those of previous authors are mentioned below. Overall McKay's Buntings are paler, sex for sex and age for age, than Snow Buntings. Birds were aged by the shape of the outermost rectrix in conjunction with the comparative plumage saturation of pigmented areas (first-year birds are usually a more faded brown color rather than nearly black), particularly when rectrices were worn enough to be of limited use (Swarth 1934, Smith 1992, Svensson 1992, Pyle 2008). Incomplete skull ossification, when noted, was used to age fall birds as being in their first year.

Male McKay's Buntings on St. Matthew vary significantly in the parts of their plumage that are black (Figure 1). In the scapulars, black is usually present only in the posterior portions, but a minority ( 2 of 56$)$ of specimens show significant black throughout the entire scapular region (leftmost bird in Figure 1; UAM 42263). Although this bird was collected to illustrate this trait, this phenotype was noticed several times on St. Matthew. Similarly, some male Snow Buntings from St. Paul have mantles and rumps that are pale enough that, without reference to the level of pigment saturation and wing pattern, they could be mistaken for female McKay's (e.g., rightmost bird in Figure 1). The extent to which the pale extremes of the Snow Bunting and the dark extremes of McKay's are due to intergradation or simply the manifestation of standing variation within a taxon is unclear. For example, Portenko (1989:300) discussed a male Snow Bunting (Zoological Institute of St. Petersburg 73953) taken on the Pribilof Islands on 10 July 1843 as a specimen "transitional" between hyperboreus and nivalis; this specimen resembles UAM 42279 (see Figure 1, third Snow Bunting from left). The continuum between the extremes and more typical looking individuals from each location suggests that, at a minimum, the extremes are not the result of rare instances of hybridization (see below regarding known hybridization and gene flow).

Females buntings of both taxa present the trickiest identification issues (Figures 2 and 3). The darkest female McKay's (leftmost bird in Figure 2) can look nearly identical to the palest female Snow (second from left in Figure 2 ) when details of the wing and tail are not visible. In these two extreme examples, the McKay's (UAM 42250) has only a small amount of dark on rectrix three, no dark in the secondaries, broad white stripes on the outer vane of the primaries, only dark smudging to the bases of the greater primary 
coverts, and only the dark of the outer vane of the outer primaries reaches the primary coverts, attributes that are mostly not visible in this photograph, nor in many field situations. In this Snow Bunting (UAM 42294), rectrix three is nearly all dark, three secondaries have dark spots on the outer vanes, the white stripes on the outer vane of the primaries are present but reduced in comparison with McKay's, the dark at the bases of the greater primary coverts is black as opposed to brownish, and the dark on both vanes of many primaries extends to the primary coverts, again visible only when the wing and tail can be seen well. The palest female McKay's (right bird in Figure 2) could easily be mistaken for a male intergrade if the bird's sex were unknown. Even in hand, some of these pale female McKay's may be nearly indistinguishable from male intergrades by plumage alone. Females in fall and winter plumage, when the feathers have significant rusty fringes that obscure underlying patterns, present the trickiest identifications between these two taxa (see Figure 3).

The wings provide some of the best identification clues in both males and females. They are also less susceptible to the wear-induced plumage changes affecting other areas. The wings of some pale first-year male Snow Buntings can cause confusion with female McKay's, most of which have some dark in the primary coverts. But the dark in the primary coverts of first-year male Snow Buntings tends to be restricted to the tips of the coverts, in contrast to female McKay's, in which the dark (when present) is more uniformly distributed and almost always present at the base of the primary coverts as well (even if absent from the middle part of the primary coverts; Figure 4). Only one of the $20 \mathrm{fe}-$ male McKay's collected in 2018 (UAM 42241, not shown) shows a pattern like a young male Snow Bunting, and the dark tips to the primary coverts of this bird are reduced to mere specks, inviting confusion with the wings of first-year male McKay's. Female McKay's with all white primary coverts can usually be distinguished from male Snow Buntings by the distribution of black in the primaries themselves. The dark in the primaries of female McKay's often reaches the primary coverts (cf. Byers et al. 1995), but when it does, it tends to be only the dark on the outer vane of the primary. In McKay's, the dark of the inner vane fades away closer to the tip of the feather, on average, creating a striped pattern on a spread wing unlike the more abrupt and uniform ending of this dark area on a male Snow Bunting (Figure 4). This difference is not always observable on a folded wing. Additionally, the white outer fringe of the outer vane on female McKay's tends to be more pronounced than in the Snow Bunting, although Snow Buntings can have some minimal fringing too. On female McKay's this fringe serves to accentuate the striped effect on a spread wing. Many (11 of 29) male McKay's older than one year have a partially dark alula (cf. Swarth 1934, Pyle 1997), and this limited black is nearly always restricted to the largest alula feather (UAM 42237, Figure 1, second from left, with dark streaks on two feathers, is an exception). By contrast, in male Snow Buntings the black, in addition to being more extensive, is almost always present in significant amounts on the two longest alula feathers (see UAM 42279 in Figure 4 for an exception). First-year male McKay's usually (15 of 19) have a limited amount of black on the second alula feather (Swarth 1934), but which feathers have dark is nearly impossible to discern unless the bird is in hand. Nearly all female Snow Buntings have the black patch of the primaries extending onto the outer secondaries, but sometimes just to the outer vane of the outermost ones (Figure 
4). A minority (8 of 32) of breeding female McKay's can also have black on the outermost secondaries (usually no more than three, exceptionally five, see Figure 3) and it is always restricted to the outer vane. Sealy (1969) interpreted this variability among McKay's as evidence of interbreeding with the Snow Bunting, but the frequency of this trait is relatively high, and may be higher in fall before the usually minimal patches on the outer vane have worn much.

Within an individual, the formative plumage may be somewhat darker than in subsequent cycles (e.g., dark on primary coverts and outer tail feathers), but there is no evidence that individuals become appreciably paler with successive molts after their second basic plumage, as has been suggested (Byers et al. 1995). The variation seen in a population is thus probably the result of individual variation and not a mix of age classes beyond the second year (and see banding anecdote in Rogers 2005). Swarth (1934:56) observed that other than in the primary coverts and alula "there is overlapping and intergrading of every degree between immatures and adults" (and see above regarding the alula in a sample much larger than Swarth's). Portenko (1989), Smith (1992), and Rogers (2005) all came to similar conclusions about paleness in relation to age, and the considerable variation in first-cycle birds at UAM easily encompasses all variation seen in older birds.

\section{SPECIFIC STATUS OF PLECTROPHENAX HYPERBOREUS}

The biological species concept is the dominant species concept in birds (e.g., AOU 1998, Dickinson and Remsen 2013). Assessment and delimitation of isolated (allopatric) populations under the biological species concept is difficult, and here I operate under the expectation that these two taxa are similar enough that they would likely interbreed were they to occur in sympatry (see Toews 2015). I draw from various lines of evidence to infer that reproductive isolation has not yet arisen, despite phenotypic diagnosability. Thus they are not biological species in the sense of Mayr (1996) and Johnson et al. (1999), as informed by current issues thought to be important in avian speciation and its delimitation. On the basis of plumage McKay's Bunting would qualify as a phylogenetic species (i.e., it is diagnosable). But no genetic marker yet studied identifies the Snow and McKay's Buntings as reciprocally monophyletic (Klicka et al. 2003, Maley and Winker 2010, Winker et al. 2018), although nuclear markers allow for a diagnosis based on allele frequencies (Maley and Winker 2010, Winker et al. 2018). Treated as a subspecies, McKay's Bunting also presumably meets the operational definitions of an evolutionarily significant unit, a distinct population segment, and/or a management unit (see Winker et al. 2007 and citations therein).

McKay's Bunting has been treated by the American Ornithologists' Union (now American Ornithological Society) as a species since the very first edition of the AOU's checklist (1886) appeared a mere two years after Robert Ridgway's description (1884). By contrast, most investigators who have since made an explicit study of plumage variation in Plectrophenax as a whole have concluded that hyperboreus is merely a subspecies of nivalis (Salomonsen 1931, Hellmayr 1938, Vaurie 1959, Portenko 1989). Many other authorities treated it as a subspecies as well (Mayr and Short 1970, Paynter 1970, Cramp and Perrins 1994), influenced by evidence of extralimital pairings of male McKay's with reported female Snow Buntings at St. Lawrence Island (Sealy 
1969). Its stable taxonomic status within the AOU checklist belies a more skeptical undercurrent, e.g., "may be conspecific" (AOU 1998:630), "recognized plumage differences are no more pronounced than among many passerine subspecies" (Maley and Winker 2007:909), although both ultimately treated them as separate species.

Ridgway himself was equivocal regarding the specific status of hyperboreus. At the time he described hyperboreus (Ridgway 1884), trinomials were given only to birds known "to intergrade in physical characters" (AOU 1886:30). As Ridgway himself put it, "every local or geographical variation of size, form, or color, no matter how slight, if reasonably constant, is just so much evidence affecting the question of the derivation of species, and no excuse for the exclusion of such evidence can be allowed" (in Stejneger 1884:79). Because McKay's Bunting is nearly 100\% diagnosable (i.e., "constant"; in 1884 Ridgway was working from seven specimens), by the concept of species at the time (long before the development of the biological species concept), it was acceptable to treat it as such. However, Ridgway's own doubts about the status of this taxon are evident from the ambiguous title of his description ("Description of a new Snow Bunting from Alaska"), the fact that he begins it with "sUBSP. CH." (i.e., subspecies characters), and the designation "Plectrophanes nivalis hyperboreus Ridgw." written in his own hand on each of the original labels of the syntypes at the U. S. National Museum (C. Milensky in litt. 2019).

Snow and McKay's buntings do not display any known prezygotic reproductive isolating mechanisms in behavior or ecology. Their songs are usually described as similar, but Plectrophenax song is relatively complex and at least in Snow Buntings subject to regional, individual, and even annual variation (Espmark 1994, Baldo et al. 2014). Even if a rigorous quantification of song showed a difference between the two, it would remain to be demonstrated that any differences affected mate choice and levels of introgression. Differences in timing of migration and habitat saturation (Winker et al. 2002, Matsuoka and Johnson 2008) may be acting as isolating mechanisms, but these are likely too porous or too recent to allow or to have resulted in speciation (see below regarding gene flow levels). Under the biological species concept, geographic isolation alone, even if reinforced by differences in phenomena such as migration timing and habitat saturation, is not considered a reproductive isolating mechanism (Mayr 1996). However, this dynamic, a form of heteropatry, can be an important driver of divergence in birds (Winker 2010) and is probably operating to some extent here: Snow Buntings appear to be uncommon during spring migration at St. Matthew Island (Winker et al. 2002), but they are scarce there at other times (see Robinson et al. 2020). For example, in June of 2003, during transect counts of 2400 McKay's Buntings, zero Snow Buntings were identified and only five (all males) were seen off transects, the latest on 5 June (Matsuoka and Johnson 2008), suggesting that the two forms are effectively allopatric during the breeding season. A gap in breeding distribution of at least $264 \mathrm{~km}$, reinforced by a process of heteropatry, may be why intergrades are not rampant, but see above regarding significant variation that could be interpreted as evidence of intergradation, and below on gene flow. Field research into mate preference and heterospecific interactions would be instructive, but any differences are likely to be minor given the overall similarities. Furthermore, in many cases levels of assortative mating must be 
very high for that factor to be an effective isolator (Irwin 2020). "It is unlikely that effective postzygotic reproductive isolating mechanisms have evolved, and fertile hybrids would be expected" (Maley and Winker 2010:10).

The differences in juvenal plumage have been adduced as evidence for species rank (Maley and Winker 2007), but, like the adult plumage, the juvenal plumage is variable, and some individuals are borderline cases (see Figure 2a in Maley and Winker 2007; visual examination of 50+ juvenal-plumaged specimens of Plectrophenax at UAM). Furthermore, recognition that the Snow Buntings and longspurs constitute their own family Calcariidae (Chesser et al. 2010) frees them from an expectation that they have a distinctive juvenal plumage as is typical in the family Emberizidae (sensu lato) in which they were previously classified. Some evidence suggests those plumages are evolutionarily conserved (see citations in Maley and Winker 2007), a situation that informed the conclusions of that study (ibid.). Graber (1955), in his review of the juvenal plumages of the Emberizidae (as previously constituted), had already pointed out that Plectrophenax does not follow those patterns. In the closely related longspurs (Calcarius, Rhynchophanes), the juvenal plumage is reminiscent of the adult female plumage, as in Plectrophenax, so there may be no reason to assume any differences reflect a deep evolutionary divide, particularly when they are subtle (a matter of shading). Whether morphological integration of adult-like characters, selection, drift, phenotypic plasticity, and/or some other mechanisms are responsible for this difference remains to be discovered.

Initial genetic work on McKay's Bunting (Maley and Winker 2010) detected only small differences from the Snow Bunting. Their estimates of gene flow in mitochondrial DNA were not seen as robust enough to be a base for taxonomic conclusions. More recent genomic work on the buntings (Winker et al. 2018) found no fixed differences between the species across 3431 ultraconserved loci, few loci at which the frequency of alleles differed widely, and an overall $F_{\mathrm{ST}}=0.034$, genomic attributes that cast doubt on the reproductive isolation of McKay's Bunting. Most importantly, this work suggests that levels of long-term gene flow between McKay's and Snow buntings, far more robust estimates than the mtDNA-based methods of Maley and Winker (2010), are higher than expected between species (3-5 individuals per generation in each direction). The interplay among selection, drift, and the levels of gene flow necessary to counter divergence in practice are only beginning to be understood, but theory suggests that under neutral conditions gene flow from one individual or more per generation will prevent divergence from progressing (see Mills and Allendorf 1995, Lenormand 2002, Wang 2004, Postma and van Noordwijk 2005, Polechová and Barton 2015, Leaché et al. 2018, Winker 2018). Under selection, this number can rise, but how high is unclear; it is probably very low in relation to effective population size (e.g., Mallet 2008). Gene-flow estimates are perhaps the best proxy we have for inferring the aggregate effects of isolating mechanisms and thus potentially informative regarding species limits. Although gene-flow estimates are sensitive to violations of the model under which they are inferred (e.g., selective neutrality), they are likely to be informative in many cases, and in this case no isolating mechanisms producing selective pressures against hybrids are known.

Snow Buntings have never been documented breeding on St. Matthew Island (Winker et al. 2002, Robinson et al. 2020). The limited evidence for 
extralimital breeding by McKay's has rarely been accompanied by detailed documentation of the phenotypes involved, but phenotypic McKay's, usually males, are seen in very small numbers, less than annually, during the summer in the Pribilof Islands and on St. Lawrence Island (see Kenyon and Phillips 1965, Sealy 1967, 1969, Kessel and Gibson 1978, Lehman 2019, S. Schuette in litt. 2019, UAM unpublished data). The male McKay's Buntings collected by Spencer Sealy on St. Lawrence Island (University of British Columbia 13274, 13327, and 13328) are typical McKay's. As a parallel to this situation, in the North Atlantic P. n. insulae from Iceland occurs in winter on the British Isles and mainland Europe (see Banks et al. 1991, Winters 2013) but occasionally breeds on Jan Mayen, the Faroe and Shetland islands, and northern Scotland, where some birds are intermediate with nominate nivalis (Nethersole-Thompson 1966, Smith 1996, Shirihai and Svensson 2018). Subspecies insulae, distinguished from nominate nivalis by being darker in nearly all the same respects that hyperboreus is paler, offers an instructive analog to which McKay's Bunting may be compared.

Current evidence suggests that McKay's Bunting has not achieved reproductive isolation from the Snow Bunting and is maintaining its distinctiveness through an effectively allopatric breeding range, possibly reinforced by differences in migration timing, philopatry, and high density of the breeding population. Barring the discovery of some very effective reproductive isolating mechanism, it seems likely that the small differences between these two taxa would break down further if they were to come into significant contact while breeding. In many ways, the recognition of considerable phenotypic (plumage) variation in Plectrophenax, requiring the congruence of several attributes to yield an identification in some cases, mirrors the necessity of a genomic diagnosis based on allele frequencies. In this sense, the phenotypic evidence is congruent with the genetic evidence, and McKay's Bunting should be considered a subspecies of the Snow Bunting. In this case, diagnosability does not a biological species make.

\section{ACKNOWLEDGMENTS}

Ildiko Szabo provided photographs of buntings in the University of British Columbia's Beaty Biodiversity Museum. Vladimir Loskot provided photographs and information on buntings in the Zoological Institute, St. Petersburg, Russia. Rob Faucett kindly provided access to the University of Washington Burke Museum collection. The Alaska Maritime National Wildlife Refuge provided permits and access to St. Matthew Island aboard the R/V Tighla $\hat{x}$. Lauren Divine of the Aleut Community of St. Paul Island kindly provided permission to work on St. Paul. Dan Gibson, Kevin Winker, Jon Dunn, James Maley, and Dan Ruthrauff provided helpful comments on the manuscript.

\section{LITERATURE CITED}

American Ornithologists' Union (AOU). 1886. The Code of Nomenclature and Checklist of North American Birds. Am. Ornithol. Union, New York.

AOU. 1998. Check-list of North American Birds, $7^{\text {th }}$ ed. Am. Ornithol. Union, Washington, DC.

Arkhipov, V. Yu., and Lawicki, L. 2016. Nearctic passerines in Russia. Dutch Birding 38:201-214. 
Baldo, S., Mennill, D. J., Guindre-Parker, S., Gilchrist, H. G., and Love, O. P. 2014. Snow Buntings sing individually distinctive songs and show inter-annual variation in song structure. Wilson J. Ornithol. 126:333-338; doi.org/10.1676/13-157.1.

Banks, K. W., Clark, H., Mackay, I. R. K., Mackay, S. G., and Sellers, R. M. 1991. Origins, population structure and movements of Snow Buntings Plectrophenax nivalis wintering in Highland Region, Scotland. Bird Study 38:10-19; doi. org/10.1080/00063659109477062.

Byers, C., Curson, J., and Olsson, U. 1995. Sparrows and Buntings: A Guide to the Sparrows and Buntings of North America and the World. Houghton Mifflin, Boston.

Campbell, R. W., Dawe, N. K., McTaggart-Cowan, I., Cooper, J. M., Kaiser, G. W., Stewart, A. C., and McNall, M. C. E. 2001. The Birds of British Columbia, vol. 4. Royal Br. Columbia Mus., Victoria.

Chesser, R. T., Banks, R. C., Barker, F. K., Cicero, C., Dunn, J. L., Kratter, A. W., Lovette, I. J., Rassmussen, P. C., Remsen, J. V. Jr., Rising, J. D., Stotz, D. F., and Winker, K. 2010. Fifty-first supplement to the American Ornithologists' Union Check-list of North American Birds. Auk 127:726-744; doi.org/10.1525/auk.2010.127.3.726.

Cramp, S., and Perrins, C. M. (eds.). 1994. Birds of the Western Palearctic, vol. IX. Oxford Univ. Press, Oxford, England.

Dement'ev, G. P., and Gladkov, N. A. 1970. Birds of the Soviet Union, vol. V. Israel Program for Scientific Translations, Jerusalem.

Dickinson, E. C., and Christidis, L. 2014. The Howard and Moore Complete Checklist of the Birds of the World, $4^{\text {th }}$ ed., vol. 2. Aves Press, Eastbourne, England.

Dickinson, E. C., and Remsen, J. V. Jr. 2013. The Howard and Moore Complete Checklist of the Birds of the World, $4^{\text {th }}$ ed., vol. 1. Aves Press, Eastbourne, England.

Espmark, Y. 1994. Individual and local variations in the song of the Snow Bunting (Plectrophenax nivalis) on Spitsbergen. Bioacoustics 6:117-133; doi.org/10.108 0/09524622.1995.9753279.

Graber, R. R. 1955. Taxonomic and adaptive features of the juvenal plumage in North American sparrows. Ph. D. dissertation, Univ. Okla., Norman.

Hellmayr, C. E. 1938. Catalogue of birds of the Americas. Zool. Ser. Field Mus. 13, part XI.

Howell, S. N. G., Corben, C., Pyle, P., and Roger, D. I. 2003. The first basic problem: A review of molt and plumage homologies. Condor 105:635-653; doi.org/10.1093/ condor/105.4.635.

Irwin, D. E. 2020. Assortative mating in hybrid zones is remarkably ineffective in promoting speciation. Am. Nat. 195, in press; doi.org/10.1086/708529.

Johnson, N. K., Remsen, J. V. Jr., and Cicero, C. 1999. Resolution of the debate over species concepts in ornithology: A new comprehensive biologic species concept, in Proc. 22nd Int. Ornithol. Congr., Durban (N. J. Adams and R. H. Slotow, eds.), pp. 1470-1482. BirdLife South Africa, Johannesburg.

Kenyon, K. W., and Phillips, R. E. 1965. Birds from the Pribilof Islands and vicinity. Auk 82:624-635; doi.org/10.2307/4083224.

Kessel, B., and Gibson, D. D. 1978. Status and distribution of Alaska birds. Studies Avian Biol. 1.

Klicka, J. T., Zink, R. M., and Winker, K. 2003. Longspurs and snow buntings: Phylogeny and biogeography of a high-latitude clade (Calcarius). Molec. Phylogen. Evol. 26:165-175; doi.org/10.1016/S1055-7903(02)00360-3.

Leaché, A. D., Zhu, T., Rannala, B., and Yang, Z. 2018. The spectre of too many species. Syst. Biol. 68:168-181; doi.org/10.1093/sysbio/syy051.

Lehman, P. 2019. The Birds of Gambell and St. Lawrence Island, Alaska. Studies Western Birds 4. W. Field Ornithol., Camarillo, CA.

Lenormand, T. 2002. Gene flow and the limits to natural selection. Trends Ecol. Evol. 17:183-189; doi.org/10.1016/S0169-5347(02)02497-7.

Lyon, B., and Montgomerie, R. 1995. Snow Bunting (Plectrophenax nivalis) and 
McKay's Bunting (Plectrophenax hyperboreus), in The Birds of North America (A. Poole and F. Gill, eds.), no. 198-199. Acad. Nat. Sci., Philadelphia; doi. org/10.2173/bow.mckbun.01.

Maley, J. M., and Winker, K. 2007. Use of juvenal plumage in diagnosing species limits: An example using buntings in the genus Plectrophenax. Auk 124:907-915; doi. org/10.1093/auk/124.3.907.

Maley, J. M., and Winker, K. 2010. Diversification at high latitudes: Speciation of buntings in the genus Plectrophenax inferred from mitochondrial and nuclear markers. Molec. Ecol. 19:785-797; doi.org/10.1111/j.1365-294X.2009.04513.x.

Mallet, J. 2008. Hybridization, ecological races and the nature of species: Empirical evidence for the ease of speciation. Philos. Trans. Royal Soc. B 363:2971-2986; doi.org/10.1098/rstb.2008.0081.

Marshall, D. B., Hunter, M. G., and Contreras, A. L. (eds.). 2003. Birds of Oregon: A General Reference. Ore. State Univ. Press, Corvallis.

Matsuoka, S. M., and Johnson, J. A. 2008. Using a multimodel approach to estimate the population size of McKay's Buntings. Condor 110:371-376; doi.org/10.1525/ cond.2008.8492.

Mayr, E. 1996. What is a species, and what is not? Philos. Sci. 63:262-277; doi. org/10.1086/289912.

Mayr, E., and Short, L. L. 1970. Species taxa of North American birds. Publ. Nuttall Ornithol. Club 9.

Mills, L. S., and Allendorf, F. W. 1995. The one-migrant-per-generation rule in conservation and management. Cons. Biol. 10:1509-1518; doi.org/10.1046/j.15231739.1996.10061509.x.

Mlodinow, S. G., and Bartels, M. 2016. Tenth report of the Washington Bird Records Committee (2010-2013). W. Birds 47:86-119; doi.org/10.21199/WB47.2.1.

Nehls, H. 2014. The records of the Oregon Bird Records Committee through April 2014. Ore. Bird Records Committee; www.orbirds.org/acceptedthroughapril2014.6.pdf.

Nethersole-Thompson, D. 1966. The Snow Bunting. Oliver and Boyd, Edinburgh.

Patten, M. A., and Unitt, P. 2002. Diagnosability versus mean differences of Sage Sparrow subspecies. Auk 119:26-35; doi.org/10.1093/auk/119.1.26.

Paynter, R. A. Jr. 1970. Subfamily Emberizinae in Check-List of Birds of the World (R. A. Paynter Jr. and R. W. Storer, eds.), vol. 13, pp. 3-214. Mus. Comp. Zool., Cambridge, MA.

Polechová, J., and Barton, N. 2015. Limits to adaptation along environmental gradients. Proc. Natl. Acad. Sci. 112:6401-6406; doi.org/10.1073/pnas.1421515112.

Portenko, L. A. 1989. Birds of the Chukchi Peninsula and Wrangel Island, vol. 2. Smithsonian Inst. Libraries and Natl. Sci. Foundation, Washington, DC.

Postma, E., and van Noordwijk, A. J. 2005. Gene flow maintains a large genetic difference in clutch size at a small spatial scale. Nature 433:65-68; doi.org/10.1038/ nature 03083 .

Pyle, P. 1997. Identification Guide to North American Birds, part I. Columbidae to Ploceidae. Slate Creek Press, Bolinas, CA.

Pyle, P. 2008. Identification Guide to North American Birds, part II. Anatidae to Alcidae. Slate Creek Press, Point Reyes Station, CA.

Ridgway, R. 1884. Description of a new Snow Bunting from Alaska. Proc. U. S. Natl. Mus. 7:69-70; doi.org/10.5479/si.00963801.412.68.

Robinson, B. W., Withrow, J. J., Richardson, R. M., Matsuoka, S. M., Gill, R. E. Jr., Johnson, A. S., Lovette, I. J., Johnson, J. A., DeGange, A. R., and Romano, M. D. 2020. Further information on the avifauna of St. Matthew and Hall islands, Bering Sea, Alaska. W. Birds 51:78-91; doi.org/10.21199/WB51.2.1.

Rogers, J. 2005. Identifying McKay’s Buntings. Birding 37:618-626.

Salomonsen, F. 1931. On the geographical variation of the Snow-Bunting (Plectrophenax nivalis). Ibis 73:57-70; doi.org/10.1111/j.1474-919X.1931.tb01504.x. 
Sealy, S. G. 1967. The occurrence and possible breeding of McKay's Bunting on St. Lawrence Island, Alaska. Condor 69:531-532; doi.org/10.2307/1366160.

Sealy, S. G. 1969. Apparent hybridization between Snow Bunting and McKay's Bunting on St. Lawrence Island, Alaska. Auk 86:350-351; doi.org/10.2307/4083511.

Shirihai, H., and Svensson, L. 2018. Handbook of Western Palearctic Birds, vol. 2. Helm, London.

Smith, R. D. 1992. Age determination, wing-feather colour and wing-length change in Snow Buntings Plectrophenax nivalis. Ringing and Migration 13:43-51; doi.or g/10.1080/03078698.1992.9674014.

Smith, R. D. 1996. Racial composition of breeding and wintering Snow Buntings Plectrophenax nivalis in the north-east Scottish uplands. Ringing and Migration 17:123-136; doi.org/10.1080/03078698.1996.9674128.

Stejneger, L. 1884. On the use of trinomials in American ornithology. Proc. U. S. Natl. Mus. 7:70-81; doi.org/10.5479/si.00963801.413.70.

Svensson, L. 1992. Identification Guide to European Passerines, $4^{\text {th }}$ ed. Br. Trust Ornithol., Thetford, England.

Swarth, H. S. 1934. Birds of Nunivak Island, Alaska. Pac. Coast Avifauna 22.

Toews, D. P. L. 2015. Biological species and taxonomic species: Will a new null hypothesis help? (A comment on Gill 2014). Auk 132:78-81; doi.org/10.1642/ AUK-14-138.1.

Vaurie, C. 1956. Systematic notes on Palearctic birds. No. 23. Fringillidae: The genera Emberiza, Calcarius, and Plectrophenax. Am. Mus. Novitates 1805.

Vaurie, C. 1959. The Birds of the Palearctic Fauna. Passeriformes. H. F. and G. Witherby, London.

Wahl, T. R., Tweit, B., and Mlodinow, S. G. (eds.). 2005. Birds of Washington. Ore. State Univ. Press, Corvallis.

Wang, J. 2004. Application of the one-migrant-per-generation rule to conservation and management. Cons. Biol. 18:332-343; doi.org/10.1111/j.1523-1739.2004.00440.x.

Winker, K. 2010. On the origin of species through heteropatric differentiation: A review and a model of speciation in migratory animals. Ornithol. Monogr. 69:1-30; doi.org/10.1525/om.2010.69.1.1.

Winker, K. 2018. Systematics, population genetics, and taxonomy, and their importance for tracking avifaunal change, in Avifaunal Change in Western North America (W. D. Shuford, R. E. Gill Jr., and C. M. Handel, eds.), pp. 453-465. Studies of Western Birds 2. W. Field Ornithol., Camarillo, CA; doi.org/10.21199/SWB3.25.

Winker, K., and Withrow, J. J. 2013. Small collections make a big impact. Nature 493:480; doi.org/10.1038/493480b.

Winker, K., and Withrow, J. J. 2017. Collectively, we need to accelerate Arctic specimen sampling. Arctic Sci. 3:515-524; doi.org/10.1139/as-2016-0037.

Winker, K., Gibson, D. D., Sowls, A. L., Lawhead, B. E., Martin, P. D., Hoberg, E. P., and Causey, D. 2002. The birds of St. Matthew Island, Bering Sea. Wilson Bull. 114:491-509; doi.org/10.1676/0043-5643(2002)114[0491:TBOSMI]2.0.CO;2.

Winker, K., Rocque, D. A., Braile, T. M., and Pruett, C. L. 2007. Vainly beating the air: Species-concept debates need not impede progress in science of conservation. Auk 63:30-44; doi.org/10.2307/40166896.

Winker, K., Glenn, T. C., and Faircloth, B. C. 2018. Ultraconserved elements (UCEs) illuminate the population genomics of a recent, high-latitude avian speciation event. PeerJ 6:e5735; doi.org/10.7717/peerj.5735.

Winters, R. 2013. Snow Bunting: Sexing, ageing and subspecies. Dutch Birding 35:7-14. 